\title{
A Simple and Efficient Synthesis of Highly Substituted Indeno[1,2-b]pyrrole and Acenaphtho[1,2-b]pyrrole Derivatives by Tandem Three-Component Reactions
}

\author{
Xiaodong Tang ${ }^{1, \dagger}$, Songlei Zhu ${ }^{1, *,+}$, Ying Ma ${ }^{1}$, Ren Wen ${ }^{2}$, Lanqi Cen ${ }^{1}$, Panwei Gong ${ }^{1}$ and \\ Jing Wang ${ }^{1, *}$ \\ 1 Department of Chemistry, School of Pharmacy, Xuzhou Medical University, Xuzhou 221004, Jiangsu, China; \\ windmillons@126.com (X.T.); yingma123@126.com (Y.M.); lanqi.cen@siat.ac.cn (L.C.); \\ g1578989778@163.com (P.G.) \\ 2 Nanjing Hicin Pharmaceutical Co., Ltd., Nanjing 210009, Jiangsu, China; 15950589107@163.com \\ * Correspondence: songleizhu@126.com (S.Z.); uncool_wj@126.com (J.W.); Tel.: +86-516-83262098 (J.W.) \\ + These authors contributed equally to this paper.
}

Academic Editor: Cimarelli Cristina

Received: 22 October 2018; Accepted: 19 November 2018; Published: 20 November 2018

\begin{abstract}
A green, convenient and tandem procedure for the efficient synthesis of highly substituted indeno[1,2-b]pyrrole and acenaphtho[1,2-b]pyrrole derivatives by domino three-component reaction of tryptamine/benzylamine, 1,3-dicarbonyl compounds and ninhydrin/ acenaphthenequinone is described. The significant features of this procedure were characterized by mild reaction conditions, high yields, operational simplicity and it being environmentally benign.
\end{abstract}

Keywords: multi-component reactions; indeno[1,2-b]pyrroles; acenaphtho[1,2-b]pyrroles

\section{Introduction}

Polysubstituted pyrroles are widely employed as versatile building blocks in synthetic organic chemistry [1-4] because of their presence in numerous natural products and drug molecules, and because they exhibit different pharmacological applications including anti-tuberculosis, anti-oxidation, antibacterial, anti-inflammatory, and antitumor properties, among others [5-7]. Among them, indeno[1,2-b]pyrroles (Figure 1A,B) are heterocycles of great importance because they can be used as antiviral agents, insecticides, herbicides and human protein kinase CK2 inhibitors [8-10]. Moreover, acenaphtho[1,2-b]pyrroles (Figure 1C), as important polycyclic fused compounds, can also be employed as potent and selective inhibitors of fibroblast growth factor receptor 1 (FGFR-1), novel Bcl-2 inhibitors, and as a valuable Mcl-1 inhibitor [11-14].
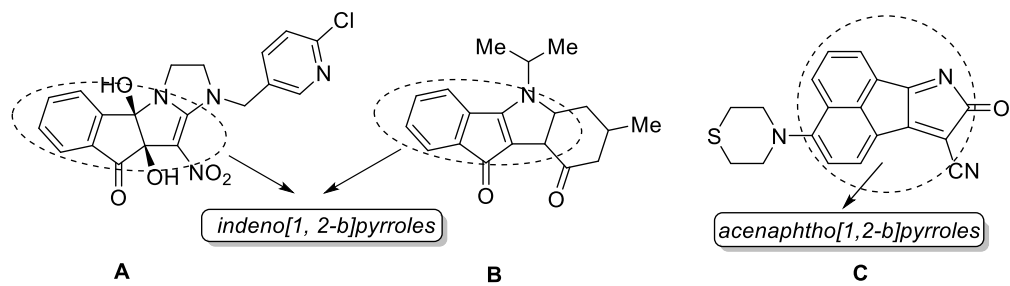

Figure 1. Biologically important indenopyrroles and acenaphthopyrroles.

The development of the design and synthesis of diverse heterocyclic compounds with valuable medicinal and biological applications is highly desirable in current organic and medicinal chemistry 
research [15-18]. Multi-component reactions (MCRs), which involve the rapid combination of three or more simple reactants in a one-pot sequential process and produce the final product containing a substructure of all starting materials, play an important role in the synthesis of complex and diverse molecules [19-21]. MCRs have attracted much attention for the construction of bioactive heterocyclic compounds, due to their high productivity, facile execution, convergence, low costs, minimal waste production and structural diversity [22-28].

Considering the importance of indeno[1,2-b]pyrrole and acenaphtho[1,2- $b]$ pyrrole derivatives and in continuation of our research on multi-component reactions [29-32], herein we report a three-component reaction of ninhydrin/acenaphthenequinone, 1,3-dicarbonyl compounds and tryptamine/benzylamine, which is an efficient and straightforward protocol for the synthesis of a serial of highly substituted indeno[1,2-b]pyrrole and acenaphtho[1,2-b]pyrrole derivatives.

\section{Results and Discussion}

Initially, we carried out the one-pot, three-component reaction of ninhydrin 1, methyl acetoacetate $\mathbf{2}$, and tryptamine $\mathbf{3}$ as a model reaction to establish the feasibility of the strategy and optimize reaction conditions (Scheme 1). The reaction was examined in different solvents including methanol, ethanol, chloroform, acetonitrile, toluene and water. As shown in Table 1, using ethanol as the solvent provided the highest yield (Table 1, Entry 7). Furthermore, the reaction was carried out at different temperatures, ranging from room temperature to refluxing. It can be seen from Table 1 that temperature had no remarkable effect on this reaction. Therefore, using ethanol as the solvent, and carrying out the reaction at room temperature, were chosen as optimal conditions for all further reactions.

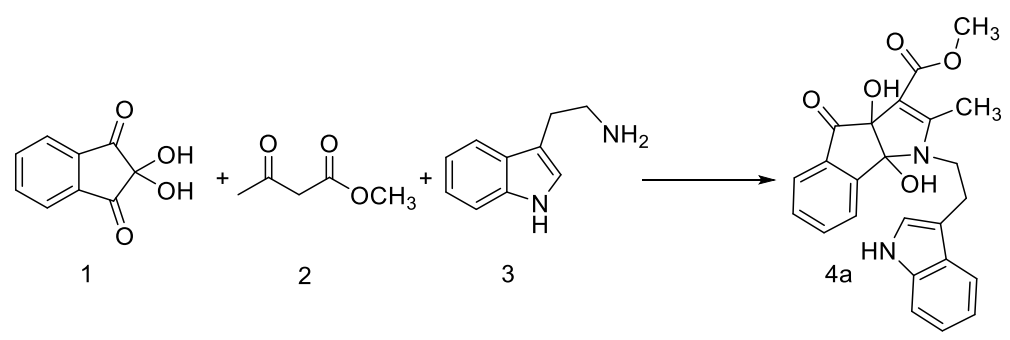

Scheme 1. Model reaction.

Table 1. Optimizing the reaction solvent for the synthesis of $\mathbf{4 a}$.

\begin{tabular}{ccccc}
\hline Entry & Solvent & Temp $\left({ }^{\circ} \mathbf{C}\right)$ & Time (h) & Yield (\%) ${ }^{\text {a }}$ \\
\hline 1 & Methanol & r.t. & 3 & 57 \\
2 & Chloroform & r.t. & 3 & 40 \\
3 & Acetonitrile & r.t. & 3 & 45 \\
4 & Toluene & r.t. & 3 & 35 \\
5 & Water & r.t. & 3 & 31 \\
7 & Ethanol & r.t. & 3 & 85 \\
8 & Ethanol & 40 & 3 & 83 \\
9 & Ethanol & reflux & 3 & 84 \\
\hline \multicolumn{5}{c}{ a Isolated yield. }
\end{tabular}

With optimum conditions determined, we explored the model reaction using different 1,3-dicarbonyl compounds with ninhydrin and tryptamine (Scheme 2). As shown in Table 2, the reaction performed smoothly in $2.5-3.5 \mathrm{~h}$, with excellent yields of $84-94 \%$. In order to expand the scope of this protocol, ninhydrin was replaced by acenaphthenequinone to react with different 1,3-dicarbonyl compounds and tryptamine (Scheme 3 ). To our delight, a new series of acenaphtho[1,2-b]pyrrole derivatives were obtained easily with satisfactory yields (Table 3). 


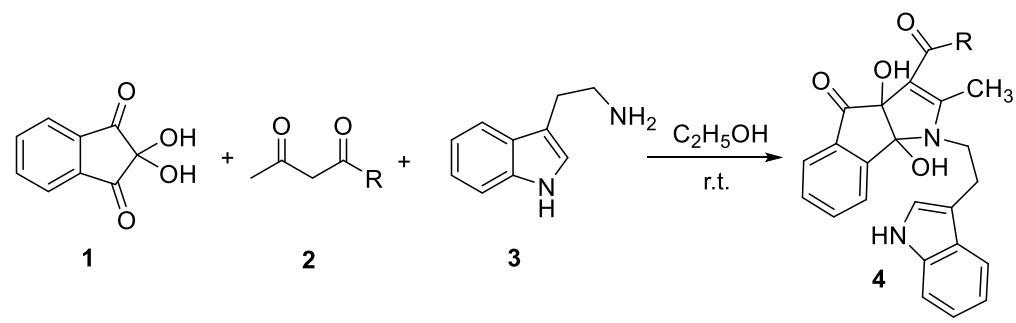

Scheme 2. The synthesis of compounds 4 .

Table 2. The synthesis of compounds 4 .

\begin{tabular}{|c|c|c|c|c|c|}
\hline Entry & Product & Structure & Time (h) & Yield $(\%)^{a}$ & m.p. $/\left({ }^{\circ} \mathrm{C}\right)$ \\
\hline 1 & $4 a$ & & 3 & 85 & 149-151 \\
\hline 2 & $4 b$ & & 2.5 & 93 & $121-123$ \\
\hline 3 & $4 c$ & & 2.5 & 92 & 101-103 \\
\hline 4 & $4 d$ & & 3 & 91 & 110-112 \\
\hline 5 & $4 e$ & & 3.5 & 94 & 100-102 \\
\hline 6 & $4 f$ & & 2.5 & 75 & $164-166$ \\
\hline
\end{tabular}




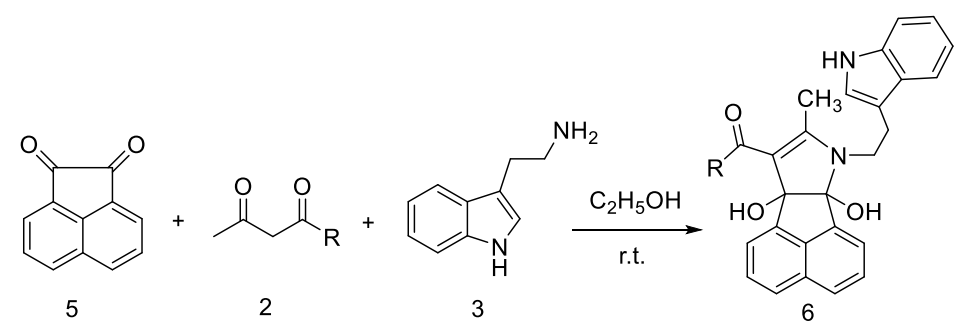

Scheme 3. The synthesis of compound 6.

Table 3. The synthesis of compound 6 .

\begin{tabular}{|c|c|c|c|c|c|}
\hline Entry & Product & Structure & Time (h) & Yield (\%) ${ }^{a}$ & m.p. $/\left({ }^{\circ} \mathrm{C}\right)$ \\
\hline 1 & $6 a$ & & 3 & 72 & $161-163$ \\
\hline 2 & $6 b$ & & 3 & 83 & 145-147 \\
\hline 3 & $6 c$ & & 2.5 & 78 & $161-163$ \\
\hline 4 & $6 d$ & & 2.5 & 70 & $112-114$ \\
\hline 5 & $6 e$ & & 3.5 & 85 & 95-97 \\
\hline
\end{tabular}

To further extend the usefulness of this methodology, the one-pot reactions of ninhydrin and 1,3-dicarbonyl compounds with benzylamine 7 were also investigated (Scheme 4), and the results are presented in Table 4.<smiles>O=C1c2ccccc2C(=O)C1(O)O</smiles><smiles>[R]C(=O)CC(C)=O</smiles>

2<smiles>NCc1ccccc1</smiles>

7<smiles>[R]C(=O)C1=C(C)NC2(O)c3ccccc3C(=O)C1(O)C2(O)Cc1ccccc1</smiles>

8

Scheme 4. The synthesis of compounds 8 . 
Table 4. The synthesis of compounds 8 .

\begin{tabular}{|c|c|c|c|c|c|}
\hline Entry & Product & Structure & Time (h) & Yield (\%) ${ }^{a}$ & m.p./ $\left({ }^{\circ} \mathrm{C}\right)$ \\
\hline 1 & $8 a$ & & 2.5 & 75 & $154-156$ \\
\hline 2 & $8 b$ & & 3 & 71 & $72-73$ \\
\hline 3 & $8 c$ & & 2.5 & 83 & $71-73$ \\
\hline 4 & $8 d$ & & 3.5 & 88 & $83-85$ \\
\hline 5 & $8 e$ & & 4 & 88 & $70-71$ \\
\hline 6 & $8 f$ & & 2.5 & 81 & 175-177 \\
\hline
\end{tabular}

A reasonable mechanism of the reaction is given in Scheme 5. Initially, the reaction between acetoacetate $\mathbf{2}$ and tryptamine $\mathbf{3}$ is to give intermediate enamine $\mathbf{9}$, which further undergoes the nucleophilic addition with the carbonyl in ninhydrin $\mathbf{1}$ to afford the intermediate 10. After isomerization of $\mathbf{1 0}$ to the aminol intermediate 11, the subsequent intermolecular $N$-cyclization afforded the target product 4 .

To verify this conversion, we carried out the model reaction with three reactants mixed simultaneously in ethanol solvent at room temperature. The target product was also formed, although only a 53\% yield of $4 \mathbf{a}$ was obtained. When acetoacetate $\mathbf{2}$ and tryptamine $\mathbf{3}$ were pre-stirred and ninhydrin 1 was added subsequently under one-pot reaction conditions without any separation, the purpose product was obtained with a satisfactory yield of $85 \%$. Therefore, this three-component reaction might be accomplished by a tandem sequential procedure, which the first condensation of 1,3-dicarbonyl compound and amine to afford intermediate enamine may facilitate to achieve better results. 

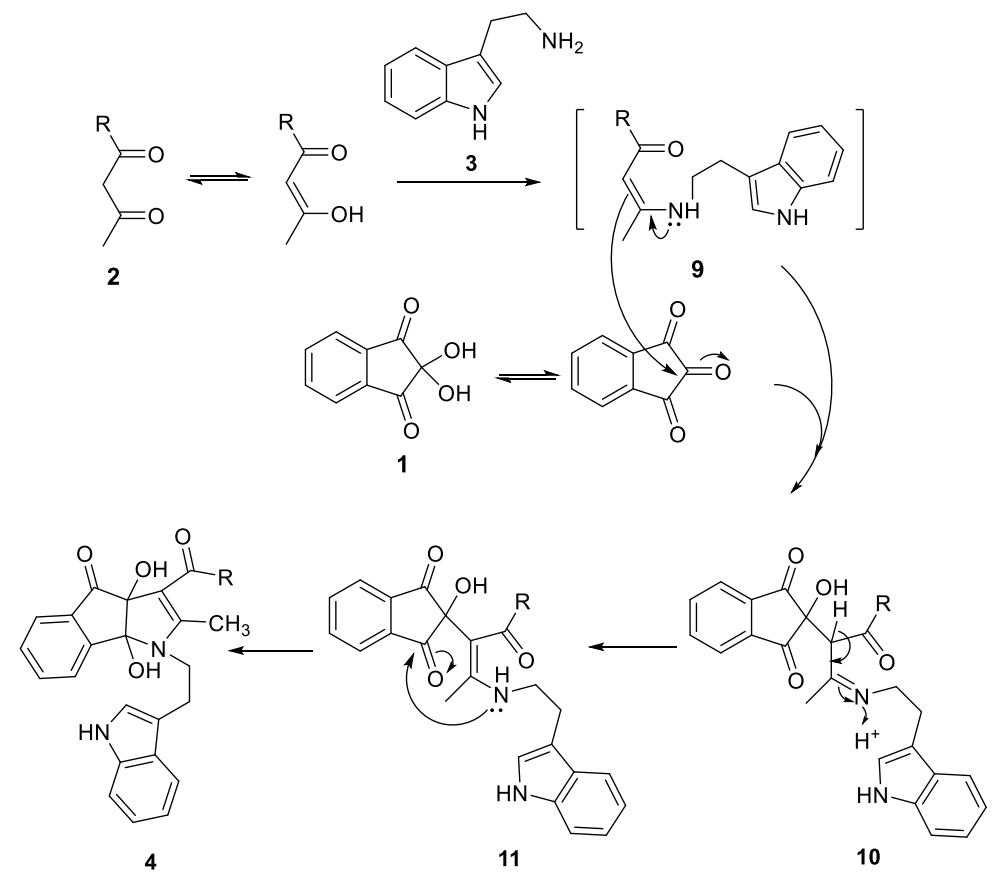

Scheme 5. Proposed mechanism for the formation of 4 .

In this study, all products were characterized by melting point, IR, NMR, and HRMS spectral data (All the data were in the supplementary). The ${ }^{1} \mathrm{H}-\mathrm{NMR}$ spectrum of compound 4a showed two singlets at 2.22 and $3.55 \mathrm{ppm}$, which are distributed to one methyl group and one methoxyl group, respectively. Four multiplets appeared at the 2.92 to $4.06 \mathrm{ppm}$ area and are related to the four protons of two linked methylene moieties. The sharp single signals at 5.67 and 6.77 were assigned to two hydroxyl groups. The aromatic protons resonated between 7.02 and 7.89, and the $\mathrm{NH}$ proton of indole was observed at $10.92 \mathrm{ppm}$. Furthermore, the structures of compounds $\mathbf{6 d}$ (Figure 2) and $\mathbf{8 f}$ (Figure 3) were also confirmed by X-ray crystallographic analysis. In the crystal structure of $\mathbf{6 d}$, the dihedral angle was formed between the acenaphthequinone plane and pyrrole plane, while in the structure of $\mathbf{8 f}$ this was between the indeno plane and pyrrole plane. Therefore, the two adjacent $\mathrm{OH}$ groups which attached to the fused side of two planes might adopt cis configuration. Furthermore, a solvent molecule of ethanol was involved in the single crystal unit of $\mathbf{6 d}$ to form co-crystal.

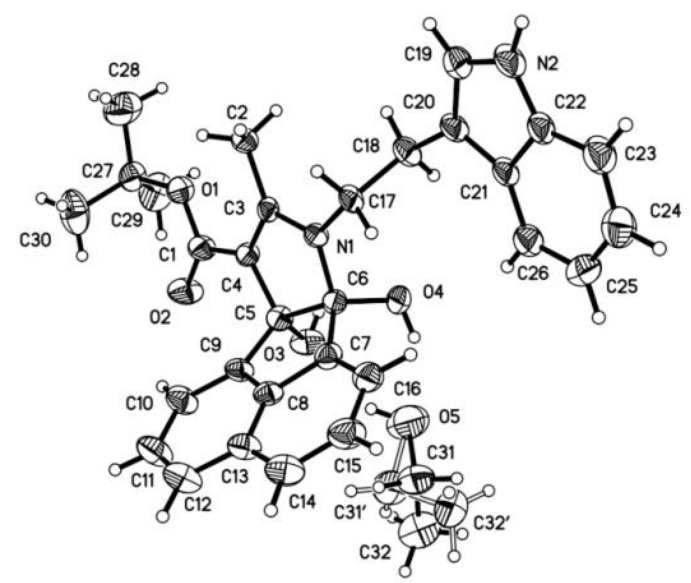

Figure 2. The crystal structure of $\mathbf{6} \mathbf{d}$ with ethanol solvent. 


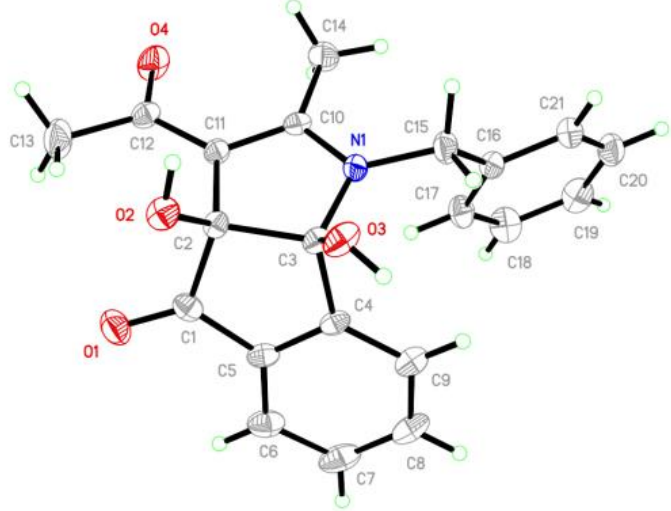

Figure 3. The crystal structure of $\mathbf{8 f}$.

\section{Materials and Methods}

\subsection{General Information}

Melting points were recorded on an Electrothermal digital melting point apparatus (Donghua, Shanghai, China) and were uncorrected. IR Spectra were recorded on a Nicolet FT-IR500 spectrophotometer (Madison, WI, USA) using KBr optics. ${ }^{1} \mathrm{H}-\mathrm{NMR}$ and ${ }^{13} \mathrm{C}-\mathrm{NMR}$ spectra were recorded on a JMTC-400/54/SS spectrometer (JEOL Ltd., Tokyo, Japan) using DMSO- $d_{6}$ as solvent and TMS as internal standard. HRMS analyses were conducted on a Bruker micro-TOF-Q-MS analyzer (Bruker Daltonics, Bremen, Germany). X-Ray diffraction data were made on a Rigaku Mercury CCD area detector with graphite monochromated Mo-Ka radiation (Rigaku, Tokyo, Japan).

\subsection{General Procedure for the Synthesis of Compounds 4, 6 and $\mathbf{8}$}

A mixture of an equimolar amount of 1,3-dicarbonyl compound $2(0.5 \mathrm{mmol})$ and tryptamine 3 $(0.5 \mathrm{mmol})$ or benzylamine $7(0.5 \mathrm{mmol})$ were stirred in ethanol at room temperature for $1 \mathrm{~h}$. Ninhydrin $1(0.5 \mathrm{mmol})$ or Acenaphthenequinone $5(0.5 \mathrm{mmol})$ was then added to the solution and stirred at room temperature for 1.5-2 $\mathrm{h}$. Completion of the reaction was monitored with TLC. The mixture was poured into cold water. The precipitate was filtered and washed with $\mathrm{EtOH}(95 \%)$. The precipitate was purified by recrystallization from EtOH to give the products 4, 6 and 8, respectively.

Methyl 1-(2-(1H-indol-3-yl)ethyl)-3a,8b-dihydroxy-2-methyl-4-oxo-1,3a,4,8b-tetrahydroindeno[1,2-b]pyrrole-3carboxylate (4a), yellow soild; m.p. $149-151^{\circ} \mathrm{C}$; IR ( $\left.\mathrm{cm}^{-1}\right)$ : 744, 1194, 1356, 1437, 1551, 1655, 1717, 3410; ${ }^{1} \mathrm{H}-\mathrm{NMR}\left(400 \mathrm{MHz}, \mathrm{DMSO}-d_{6} ; \delta, \mathrm{ppm}\right): 2.22$ (s, 3H, $\left.\mathrm{CH}_{3}\right), 2.92-3.00(\mathrm{~m}, 1 \mathrm{H}, \mathrm{CH}), 3.14-3.21(\mathrm{~m}, 1 \mathrm{H}$, $\mathrm{CH}), 3.55$ (s, 3H, $\left.\mathrm{OCH}_{3}\right), 3.72-3.80(\mathrm{~m}, 1 \mathrm{H}, \mathrm{CH}), 3.98-4.06(\mathrm{~m}, 1 \mathrm{H}, \mathrm{CH}), 5.67(\mathrm{~s}, 1 \mathrm{H}, \mathrm{OH}), 6.77(\mathrm{~s}, 1 \mathrm{H}$, $\mathrm{OH}), 7.02(\mathrm{t}, J=8.0 \mathrm{~Hz}, 1 \mathrm{H}, \mathrm{ArH}), 7.10(\mathrm{t}, J=8.0 \mathrm{~Hz}, 1 \mathrm{H}, \mathrm{ArH}), 7.29(\mathrm{~s}, 1 \mathrm{H}, \mathrm{ArH}), 7.37(\mathrm{~d}, J=8.0 \mathrm{~Hz}$, $1 \mathrm{H}, \mathrm{ArH}), 7.56(\mathrm{t}, J=8.0 \mathrm{~Hz}, 1 \mathrm{H}, \mathrm{ArH}), 7.63(\mathrm{~d}, J=8.0 \mathrm{~Hz}, 1 \mathrm{H}, \mathrm{ArH}), 7.70-7.77$ (m, 2H, ArH), 7.89 (d, $J=8.0 \mathrm{~Hz}, 1 \mathrm{H}, \mathrm{ArH}), 10.92(\mathrm{~s}, 1 \mathrm{H}, \mathrm{NH}) ;{ }^{13} \mathrm{C}-\mathrm{NMR}\left(100 \mathrm{MHz}, \mathrm{DMSO}-d_{6} ; \delta, \mathrm{ppm}\right): 13.16,27.45,43.10$, 50.15, 84.97, 94.74, 95.15, 111.74, 111.99, 118.86, 118.97, 121.56, 123.50, 123.72, 124.96, 127.62, 130.64, 135.51, 136.01, 136.73, 148.68, 160.53, 166.27, 198.83. HRMS calcd. for $\mathrm{C}_{24} \mathrm{H}_{22} \mathrm{~N}_{2} \mathrm{O}_{5}[\mathrm{M}+\mathrm{H}]^{+}: 418.1529$, found: 418.1545 .

Methyl 7-(2-(1H-indol-3-yl)ethyl)-6b,9a-dihydroxy-8-methyl-6b,9a-dihydro-7H-acenaphtho-[1,2-b]pyrrole-9carboxylate (6a), white soild; m.p. $161-163{ }^{\circ} \mathrm{C}$; IR $\left(\mathrm{cm}^{-1}\right)$ : 746, 787, 833, 1003, 1080, 1198, 1383, 1439, 1560, 1637, 3421; ${ }^{1} \mathrm{H}-\mathrm{NMR}$ (400 MHz, DMSO-d $;$; $\delta$ ppm): 2.19 (s, 3H, CH $), 2.84-2.91(\mathrm{~m}, 1 \mathrm{H}, \mathrm{CH})$, 3.06-3.13 (m, 1H, CH), $3.66\left(\mathrm{~s}, 3 \mathrm{H}, \mathrm{CH}_{3}\right), 3.70-3.76\left(\mathrm{~m}, 2 \mathrm{H}, \mathrm{CH}_{2}\right), 5.51(\mathrm{~s}, 1 \mathrm{H}, \mathrm{OH}), 6.49(\mathrm{~s}, 1 \mathrm{H}, \mathrm{OH})$, $6.99(\mathrm{t}, J=8.0 \mathrm{~Hz}, 1 \mathrm{H}, \mathrm{ArH}), 7.07(\mathrm{t}, J=8.0 \mathrm{~Hz}, 1 \mathrm{H}, \mathrm{ArH}), 7.25(\mathrm{~s}, 1 \mathrm{H}, \mathrm{ArH}), 7.34(\mathrm{~d}, J=8.0 \mathrm{~Hz}, 1 \mathrm{H}$, ArH), 7.52-7.62 (m, 4H, ArH), $7.70(\mathrm{~d}, J=8.0 \mathrm{~Hz}, 1 \mathrm{H}, \mathrm{ArH}), 7.76-7.82(\mathrm{~m}, 2 \mathrm{H}, \mathrm{ArH}), 10.90$ (s, $1 \mathrm{H}$, $\mathrm{NH}) ;{ }^{13} \mathrm{C}-\mathrm{NMR}\left(100 \mathrm{MHz}, \mathrm{DMSO}-d_{6} ; \delta, \mathrm{ppm}\right): 13.05,19.11,27.00,43.19,50.08,56.58,87.65,99.60$, $100.90,111.96,112.03,118.75,118.86,119.60,121.57,123.58,123.85,125.27,127.62,128.27,129.10,131.30$, 
$136.45,136.75,142.28,145.98,160.48,166.46$. HRMS calcd. for $\mathrm{C}_{27} \mathrm{H}_{24} \mathrm{~N}_{2} \mathrm{O}_{4}[\mathrm{M}+\mathrm{H}]^{+}:$440.1736, found: 440.1745 .

Methyl 1-benzyl-3a,8b-dihydroxy-2-methyl-4-oxo-1,3a,4,8b-tetrahydroindeno [1,2-b]pyrrole-3-carboxylate (8a), white soild; m.p. $154-156{ }^{\circ} \mathrm{C}$; IR ( $\left.\mathrm{cm}^{-1}\right)$ : 784, 823, 1101, 1296, 1427, 1562, 1635, 1721, 3398; ${ }^{1} \mathrm{H}-\mathrm{NMR}$ (400 MHz, DMSO- $\left.d_{6} ; \delta, \mathrm{ppm}\right): 1.93\left(\mathrm{~s}, 3 \mathrm{H}, \mathrm{CH}_{3}\right), 3.50\left(\mathrm{~s}, 3 \mathrm{H}, \mathrm{CH}_{3}\right), 4.75(\mathrm{~d}, J=16.0 \mathrm{~Hz}, 1 \mathrm{H}, \mathrm{CH}), 5.12(\mathrm{~d}$, $J=16.0 \mathrm{~Hz}, 1 \mathrm{H}, \mathrm{CH}), 5.70(\mathrm{~s}, 1 \mathrm{H}, \mathrm{OH}), 6.79(\mathrm{~s}, 1 \mathrm{H}, \mathrm{OH}), 7.19-7.29(\mathrm{~m}, 5 \mathrm{H}, \mathrm{ArH}), 7.53(\mathrm{t}, J=8.0 \mathrm{~Hz}, 1 \mathrm{H}$, ArH), 7.65-7.70(m, 2H, ArH), 7.77 (d, $J=8.0 \mathrm{~Hz}, 1 \mathrm{H}, \mathrm{ArH}) ;{ }^{13} \mathrm{C}-\mathrm{NMR}\left(100 \mathrm{MHz}, \mathrm{DMSO}-d_{6} ; \delta, \mathrm{ppm}\right)$ : 13.65, 45.38, 50.20, 85.04, 94.63, 95.59, 123.46, 125.27, 127.23, 127.37, 128.84, 130.65, 135.49, 135.86, 139.40, 148.54, 160.86, 166.19, 198.81. HRMS calcd. for $\mathrm{C}_{21} \mathrm{H}_{19} \mathrm{NO}_{5}[\mathrm{M}+\mathrm{H}]^{+}: 365.1263$, found: 365.1279.

\section{Conclusions}

In summary, we have developed a convenient three-component reaction for the preparation of some highly substituted indeno[1,2-b]pyrrole and acenaphtho[1,2-b]pyrrole derivatives in high yields. This protocol offers several advantages such as easy work-up, mild reaction times, as well as readily available starting materials, which makes it a useful and attractive process for the synthesis of the biologically important polysubstituted pyrroles.

Supplementary Materials: Supplementary data associated with this article are available online.

Author Contributions: Conceptualization, J.W.; methodology, S.Z.; synthesis, Y.M.; L.C. and P.G.; crystal structure analysis, X.T.; writing—original draft preparation, R.W.; writing—review and editing, S.Z.; supervision, J.W.

Funding: This research was funded by the Scientific Research Foundation for Excellent Talents in Xuzhou Medical University grant number [D2016016] and the Project of Science and Technology of Xuzhou grant number [XM171140].

Conflicts of Interest: The authors declare no conflict of interest.

\section{References}

1. Fürstner, A. Chemistry and biology of roseophilin and the prodigiosin alkaloids: A survey of the last 2500 years. Angew. Chem. Int. Ed. Engl. 2003, 42, 3582-3603. [CrossRef] [PubMed]

2. Fürstner, A.; Szillat, H.; Gabor, B.; Mynott, R. Platinum- and acid-catalyzed enyne metathesis reactions: Mechanistic studies and applications to the syntheses of streptorubin B and metacycloprodigiosin. J. Am. Chem. Soc. 1998, 120, 8305-8314. [CrossRef]

3. Lipshutz, B.H. Five-membered heteroaromatic rings as intermediates in organic synthesis. Chem. Rev. 1986, 86, 795-819. [CrossRef]

4. Balme, G. Pyrrole syntheses by multicomponent coupling reactions. Angew. Chem. Int. Ed. 2004, 43, 6238-6241. [CrossRef] [PubMed]

5. Lehuédé, J.; Fauconneau, B.; Barrier, L.; Ourakow, M.; Piriou, A.; Vierfond, J. Synthesis and antioxidant activity of new tetraarylpyrroles. Eur. J. Med. Chem. 1999, 34, 991-996. [CrossRef]

6. Bürli, R.W.; Jones, P.; McMinn, D.; Le, Q.; Duan, J.X.; Kaizerman, J.A.; Difuntorum, S.; Moser, H.E. DNA binding ligands targeting drug-resistant Gram-positive bacteria. Part 2: C-terminal benzimidazoles and derivatives. Bioorg. Med. Chem. Lett. 2004, 14, 1259-1263. [CrossRef] [PubMed]

7. Denny, W.A.; Rewcastle, G.W.; Baguley, B.C. Potential antitumor agents. 59. Structure-activity relationships for 2-phenylbenzimidazole-4-carboxamides, a new class of "minimal" DNA-intercalating agents which may not act via topoisomerase II. J. Med. Chem. 1990, 33, 814-819. [CrossRef] [PubMed]

8. Fu, X.; Chen, J.; Li, G.; Liu, Y. Diverse reactivity of zirconacyclocumulenes derived from coupling of benzynezirconocenes with 1,3-butadiynes towards acyl cyanides: Synthesis of indeno[2,1-b]pyrroles or [3]cumulenones. Angew. Chem. Int. Ed. 2009, 48, 5500-5504. [CrossRef] [PubMed]

9. Chen, N.; Meng, X.; Zhu, F.; Cheng, J.; Shao, X.; Li, Z. Tetrahydroindeno $\left[1^{\prime}, 2^{\prime}: 4,5\right]$ pyrrolo[1,2-a]imidazol-5(1H)ones as novel neonicotinoid insecticides: Reaction selectivity and substituent effects on the activity level. J. Agric. Food. Chem. 2015, 63, 1360-1369. [CrossRef] [PubMed] 
10. Jabor, G.G.; Bouaziz, Z.; Winter, E.; Daflon-Yunes, N.; Aichele, D.; Nacereddine, A.; Marminon, C.; Valdameri, G.; Zeinyeh, W.; Bollacke, A.; et al. Converting potent indeno[1,2-b]indole inhibitors of protein kinase CK2 into selective inhibitors of the breast cancer resistance protein ABCG2. J. Med. Chem. 2015, 58, 265-277. [CrossRef] [PubMed]

11. Zhang, Z.; Wu, G.; Gao, J.; Song, T. Inclusion complex of a Bcl-2 inhibitor with cyclodextrin: Characterization, cellular accumulation, and in vivo antitumor activity. Mol. Pharm. 2010, 7, 1348-1354. [CrossRef] [PubMed]

12. Zhang, Z.; Wu, G.; Xie, F.; Song, T.; Chang, X. 3-Thiomorpholin-8-oxo-8H-acenaphtho[1,2-b]pyrrole-9-carbonitrile (S1) based molecules as potent, dual inhibitors of B-cell lymphoma 2 (Bcl-2) and myeloid cell leukemia sequence 1 (Mcl-1): Structure-based design and structure-activity relationship studies. J. Med. Chem. 2011, 54, 1101-1105. [CrossRef] [PubMed]

13. Zhang, Z.; Yang, H.; Wu, G.; Li, Z.; Song, T.; Li, X.Q. Probing the difference between $\mathrm{BH}_{3}$ groove of Mcl-1 and Bcl-2 protein: Implications for dual inhibitors design. Eur. J. Med. Chem. 2011, 46, 3909-3916. [CrossRef] [PubMed]

14. Song, T.; Li, X.; Chang, X.; Liang, X.; Zhao, Y.; Wu, G.; Xie, S.; Su, P.; Wu, Z.; Feng, Y.; Zhang, Z. 3-Thiomorpholin-8-oxo-8H-acenaphtho[1,2-b]pyrrole-9-carbonitrile (S1)derivatives as pan-Bcl-2-inhibitors of Bcl-2, Bcl-xL and Mcl-1. Bioorg. Med. Chem. 2013, 21, 11-20. [CrossRef] [PubMed]

15. Schreiber, S.L. Target-oriented and diversity-oriented organic synthesis in drug discovery. Science 2000, 287, 1964-1969. [CrossRef] [PubMed]

16. Thompson, L.A. Recent applications of polymer-supported reagents and scavengers in combinatorial, parallel, or multistep synthesis. Curr. Opin. Chem. Biol. 2000, 4, 324-337. [CrossRef]

17. Lu, L.Q.; Chen, J.R.; Xiao, W.J. Development of cascade reactions for the concise construction of diverse heterocyclic architectures. Acc. Chem. Res. 2012, 45, 1278-1293. [CrossRef] [PubMed]

18. Wang, Y.; Lu, H.; Xu, P.F. Asymmetric catalytic cascade reactions for constructing diverse scaffolds and complex molecules. Acc. Chem. Res. 2015, 48, 1832-1844. [CrossRef] [PubMed]

19. Domling, A. Recent developments in isocyanide based multicomponent reactions in applied chemistry. Chem. Rev. 2006, 106, 17-89. [CrossRef] [PubMed]

20. Orru, R.V.A.; Degreef, M. Recent advances in solution-phase multicomponent methodology for the synthesis of heterocyclic compounds. Synthesis 2003, 10, 1471-1499. [CrossRef]

21. Hulme, C.; Gore, V. "Multi-component reactions: Emerging chemistry in drug discovery" from xylocain to crixivan. Curr. Med. Chem. 2003, 10, 51-80. [CrossRef] [PubMed]

22. Knapp, J.M.; Zhu, J.S.; Tantillo, D.J.; Kurth, M.J. Multicomponent assembly of highly substituted indoles by dual palladium-catalyzed coupling reactions. Angew. Chem. Int. Ed. 2012, 51, 10588-10591. [CrossRef] [PubMed]

23. Zeng, L.Y.; Cai, C. Iodine catalyzed one-pot multicomponent synthesis of a library of compounds containing tetrazolo[1,5-a]pyrimidine core. J. Comb. Chem. 2010, 12, 35-40. [CrossRef] [PubMed]

24. Bienaymé, H.; Hulme, C.; Oddon, G.; Schmitt, P. Maximizing synthetic efficiency: Multi-component transformations lead the way. Eur. J. Chem. 2000, 6, 3321-3329. [CrossRef]

25. Kumaravel, K.; Vasuki, G. Multi-component reactions in water. Curr. Org. Chem. 2009, 13, $1820-1841$. [CrossRef]

26. Koopmanschap, G.; Ruijter, E.; Orru, R.V. Isocyanide-based multicomponent reactions towards cyclic constrained peptidomimetics. Beilstein. J. Org. Chem. 2014, 10, 544-598. [CrossRef] [PubMed]

27. Wang, K.; Kim, D.B.; Domling, A. Cyanoacetamide MCR (III): Three-component Gewald reactions revisited. J. Comb. Chem. 2010, 12, 111-118. [CrossRef] [PubMed]

28. Dömling, A.; Wang, W.; Wang, K. Chemistry and biology of multicomponent reactions. Chem. Rev. 2012, 112, 3083-3135. [CrossRef] [PubMed]

29. Wen, R.; Cen, L.Q.; Ma, Y.; Wang, J.; Zhu, S.L. One-pot, five-component 1,3-dipolar cycloaddition: A facile synthesis of spiropyrrolidine and spiropyrrolizidine derivatives. Tetrahedron. Lett. 2018, 59, 1686-1690. [CrossRef]

30. Wang, J.; Li, J.; Liu, H.Z.; Xu, Z.; Zhu, S.L. A Facile and Efficient Synthesis of Spiro[indoline-3,5'-pyrido [2,3-d]pyrimidine] Derivatives via Microwave-assisted Multicomponent Reactions. Lett. Org. Chem. 2015, 12, 62-66. [CrossRef] 
31. Li, J.; Wang, J.; Xu, Z.; Zhu, S. Combinatorial synthesis of functionalized spirooxindole-pyrrolidine/pyrrolizidine/ pyrrolothiazole derivatives via three-component 1,3-dipolar cycloaddition reactions. ACS Comb. Sci. 2014, 16, 506-512. [CrossRef] [PubMed]

32. Zhu, S.L.; Wang, J.; Xu, Z.; Li, J. An efficient one-pot synthesis of pyrano[3,2-c]quinolin-2,5-dione derivatives catalyzed by L-proline. Molecules 2012, 17, 13856-13863. [CrossRef] [PubMed]

Sample Availability: Samples of the compounds are available from the authors.

(C) 2018 by the authors. Licensee MDPI, Basel, Switzerland. This article is an open access article distributed under the terms and conditions of the Creative Commons Attribution (CC BY) license (http://creativecommons.org/licenses/by/4.0/). 